\title{
New technologies, skill shortages and training policy: a comparative approach between branches of industry
}

Citation for published version (APA):

van Dam, J. W., \& van der Velden, R. K. W. (1991). New technologies, skill shortages and training policy: a comparative approach between branches of industry. Researchcentrum voor Onderwijs en Arbeidsmarkt, Faculteit der Economische Wetenschappen. ROA Working Papers No. 3E https://doi.org/10.26481/umarow.199103E

Document status and date:

Published: 01/01/1991

DOI:

10.26481/umarow.199103E

Document Version:

Publisher's PDF, also known as Version of record

\section{Please check the document version of this publication:}

- A submitted manuscript is the version of the article upon submission and before peer-review. There can be important differences between the submitted version and the official published version of record.

People interested in the research are advised to contact the author for the final version of the publication, or visit the DOI to the publisher's website.

- The final author version and the galley proof are versions of the publication after peer review.

- The final published version features the final layout of the paper including the volume, issue and page numbers.

Link to publication

\footnotetext{
General rights rights.

- You may freely distribute the URL identifying the publication in the public portal. please follow below link for the End User Agreement:

www.umlib.nl/taverne-license

Take down policy

If you believe that this document breaches copyright please contact us at:

repository@maastrichtuniversity.nl

providing details and we will investigate your claim.
}

Copyright and moral rights for the publications made accessible in the public portal are retained by the authors and/or other copyright owners and it is a condition of accessing publications that users recognise and abide by the legal requirements associated with these

- Users may download and print one copy of any publication from the public portal for the purpose of private study or research.

- You may not further distribute the material or use it for any profit-making activity or commercial gain

If the publication is distributed under the terms of Article $25 \mathrm{fa}$ of the Dutch Copyright Act, indicated by the "Taverne" license above, 


\section{NEW TECHNOLOGIES, SKILL SHORTAGES AND \\ TRAINING POLICY: A COMPARATIVE APPROACH \\ BETWEEN BRANCHES OF INDUSTRY}

ROA-W-1991/3E

J.W. van Dam, R.K.W. van der Velden

Paper presented at the 2nd International Conference for Corporate Training for Effective

Performance; 25-27 september 1991, University of Twente, Enschede, the Netherlands.

RESEARCH CENTRE FOR EDUCATION AND LABOUR MARKET

Faculty of Economic Sciences

Rijksuniversiteit Limburg

Maastricht, November 1991 
Dam, J.W. van

New technologies, skill shortages and training policy: a comparative approach between branches of industry / J.W. van Dam and R.K.W. van der Velden. - Maastricht: Research Centre for Education and Labour Market, Faculty of Economic Sciences, Rijksuniversiteit Limburg. (Werkdocument $=$ Working paper / Researchcentrum voor Onderwijs en Arbeidsmarkt, ISSN 0922-4645; 1991/3E)

Met lit. opg.

ISBN 90-5321-070-9 in ringband

Trefw.: technische innovatie en nascholing; beleid. 


\section{CONTENTS}

1. INTRODUCTION

2. TECHNOLOGICAL DEVELOPMENTS, EMPLOYMENT STRUCTURE AND QUALIFICATION NEEDS 


\section{SUMMARY}

This paper, first, gives an overview of recent theoretical and empirical literature on the relation between technological developments and qualification structure. After that, the results of a descriptive comparison for the different training policies in four branches of industry are given. The possibilities for an adequate training policy seem to be determined by two characteristics of the sector: the level of organisation and the level of competition.

The most adequate response was found in the printing industry, with a high level of internal organisation. Though the health care also has a high level of internal and external regulation, training policy is less succesfull. The metallurgic sector has a low level of internal organisation, which makes a stable and widely supported training policy towards new technologies very unlikely. The office automation has no organisation at all: training policy depends on the producers of hard-, soft- and courseware. 


\section{INTRODUCTION}

In most of the industrialised countries a part of the public debate in recent years has been directed towards the relation between educational policy, labour market and the role of the government and intermediary organisations. In Holland the Rauwenhoff-Commission has published in 1990 the report 'Naar een werkzaam traject'. In Germany the 'Enquete-Kommission des Deutschen Bundestages' has publicated in Oktober 1990 the report 'Zukunftige Bildungspolitik-Bildung 2000'. The USA has had in the eighties the famous report 'A Nation at Risk' which influenced a great deal of the discussions held in the American Society for Training and Development (ASTD), an advisory board of the federal government. In Great-Britain, the Training Agency and the Manpower Services Commission conducted the nation-wide 'Funding Study' to the funding of vocational education and training.

This paper' is based on a research project 'Skills Shortages in Limburg', which has been part of the EC-project 'Skills Shortages in the EC', commissioned by the EC-Task Force on Human Resources, Youth and Development. The objective of the EC-project has been to contribute to the provision of a Communities strategy on skill needs and related training requirements in the 1990 s based upon factual evidence and examples of best practice. The project has been carried out in 20 regions within the EC. The dutch part of the project was undertaken by the Research Centre for Education and Labour Market (ROA) in Maastricht ${ }^{2}$.

In this paper we first review a few theories on the relation between technological developments, employment structure and qualification needs. Next, we will consider a few cases which show different responses to technological developments. These differences are due to the level of organisation and the level of market competition in the specific branch. Training policy is found to be more adequate in the branches which are characterised by a high level of internal regulations combined with a high level of competitiveness.

1. We would like to thank L. Borghans for helpfull comments. Please send your reaction to ROA, P.O.Box 616, NL-6200 MD Maastricht.

2. In this project, G.W.M. Ramaekers did the research for the Office Automation Sector. 


\section{TECHNOLOGICAL DEVELOPMENTS, EMPLOYMENT STRUCTURE AND QUALIFICATION NEEDS}

In the seventies, discussion on the effects of technological developments on the labour market structure was dominated by advocates and opponents of the upgrading theory. The advocates argued that work was becoming increasingly complex as a result of technological developments. The requirements set for employees would therefore be ever higher, which would result in a general raising of the required training level. The opponents, on the other hand, supposed that as a result of technological development work would become increasingly routine, which would have the effect of lowered required training level (the downgrading theory). Another variant was the polarisation theory, which suggested that higher as well as lower functions will expand, at the cost of middle management functions.

Empirical research in the Netherlands, by Huijgen et al. (1983) and Huijgen (1989) into the development of the qualitative structure of employment shows that the average skill level has risen over the period 1960-1971. However, for skilled and unskilled manual workers and for non-manual employees, considered separately, the average skill level has fallen (the positive net effect is caused by a shift in the mix of manual and non-manual workers). In addition, a certain polarisation of the occupational structure seems to have occurred in this period. This polarisation continued in the period 1971 to 1977, while the average skill level remained practically the same. In the period of 1977 to 1985, the average skill level again rose substantially. This rise appears to be caused especially by shifts in the employment structure within sectors, and hardly at all by shifts between sectors. Sectoral and international research (Aalders, 1990) points into the same direction: in general there has been a rise in the skill level, often linked to a polarisation of the occupational structure.

Theories suggesting unambiguous effects of technological development on the employment structure might be considered as naïve, because of their static and deterministic character (Van Hoof \& Dronkers, 1980). In the first place, there appears to be a large gap between technological development on the one hand, and the pattern of the division of labour on the other hand. This seems to be a question of 'organisational choice' rather than 'technological determinism'. The division of labour and the related qualitative structure of employment are determined not only by the technological level, but also by factors such as competitive position, labour market relations, and strategic management behaviour.

In the second place, it seems to be sensible to consider the effects of technology on employment structures from a dynamic perspective. Flynn (1988) points out that the 
introduction of new technology requires high-quality labour. Unfamiliarity with new technology may mean that, in the early phases, the training requirements of the work-force have been set too high. Over time, there will be a certain standardisation of activities and the level of qualifications required will go down. The effect of technological development on the employment structure, therefore, is determined to a large extent by the phase the company is in.

A number of recent studies give a more discriminating view of the consequences of technological developments. Hövels et al. (1988) show that technological developments in actual practice of professional engineers have led to a broadening of the qualification requirements: attention now is also focussed on other disciplines (in particular computer science). Furthermore, higher requirements are set for general skills, for instance problem solving abilities, application to work, flexibility, communication skills and commitment. The technological developments have led to higher training requirements, partly made possible by the over-supply of higher-educated.

Muysken et al. (1990) performed research in four sectors: banking, construction industry, chemical and rubber industry, and the wood and construction material industry. In general, technological innovations seem to lead to savings in labour, which are sometimes substantial. Demand-related factors may, however, be important in compensating for (or enhancing) the negative effect of increased productivity on employment. The growth in volume of transactions, for instance, has compensated for the negative effect of automation on employment in the banking sector. The occupational structure has remained relatively stable. Major changes seem to have occurred in the structure and content of the work. There is a visible trend towards task integration and flexibility. Less accent is put on specific professional skills and more on skills such as learning ability, ability to take responsibility, and flexibility. This requires a reassessment of the training level. The conclusion is that the presence of sufficient highly trained personnel increases the diffusion of technology.

The increased importance of more general qualifications is not only due to the introduction of new technologies; the drastic changes in the market are also important. The shift from a 'seller's market' to a 'buyer's market' needs an other attitude towards customers and the production-process: the life cycle of products is shorter, there is more diversification and aspects as terms of delivery and product quality have become much more important. An enterprise organised on Taylorist principles would be too rigid to comply with these new market demands (Rapportage Arbeidsmarkt, 1990). The central ideas in modern work organisation are: less hierarchical organisation of work, decentralisation of responsibilities, integration of tasks, 
maximum employment of available human resources, quality control, and innovations in logistic management (Just-in-Time). Because of that, broad deployability, flexibility, and client orientation are important skills.

Muysken et al. (1990) have formulated the theory that the introduction of information technology has led to a shift from sector-specific technology to more generic technologies (e.g. PC's, robots) not bound to a particular sector. Parallel to this development, labour has acquired a different character: from product-related labour with singular manual actions to processrelated labour wich needs a wide range of varying skills. The research results appear to give this theory some support. It should, however, be noted that there will always be a certain amount of product-related labour and that the boundary between process and product-related labour cannot always be clearly defined. The shift to more process-related labour could, according to several authors (Hövels et al., 1988; Mandon, 1988) result in dissolving the boundaries between occupations and the disappearance of the strict line between, for instance, administrative and production work. This would mean that the possibilities of substitution and mobility in the labour market would increase. The empirical results do not as yet confirm this: from research among engineers with a Higher Technical training (HTS) it appeared that horizontal substitution possibilities (especially between electric and mechanical engineers) have not significantly increased (Hövels et al., 1988), even though a broadening of the qualification requirements was noted. 


\section{TECHNOLOGICAL DEVELOPMENTS AND TRAINING POLICY}

As is shown in section 2 and scheme 1, technological developments have a great impact on the qualification structure, both in a quantitative and a qualitative sense.

Scheme 1. Model for the relations between technology, labour market and education and training

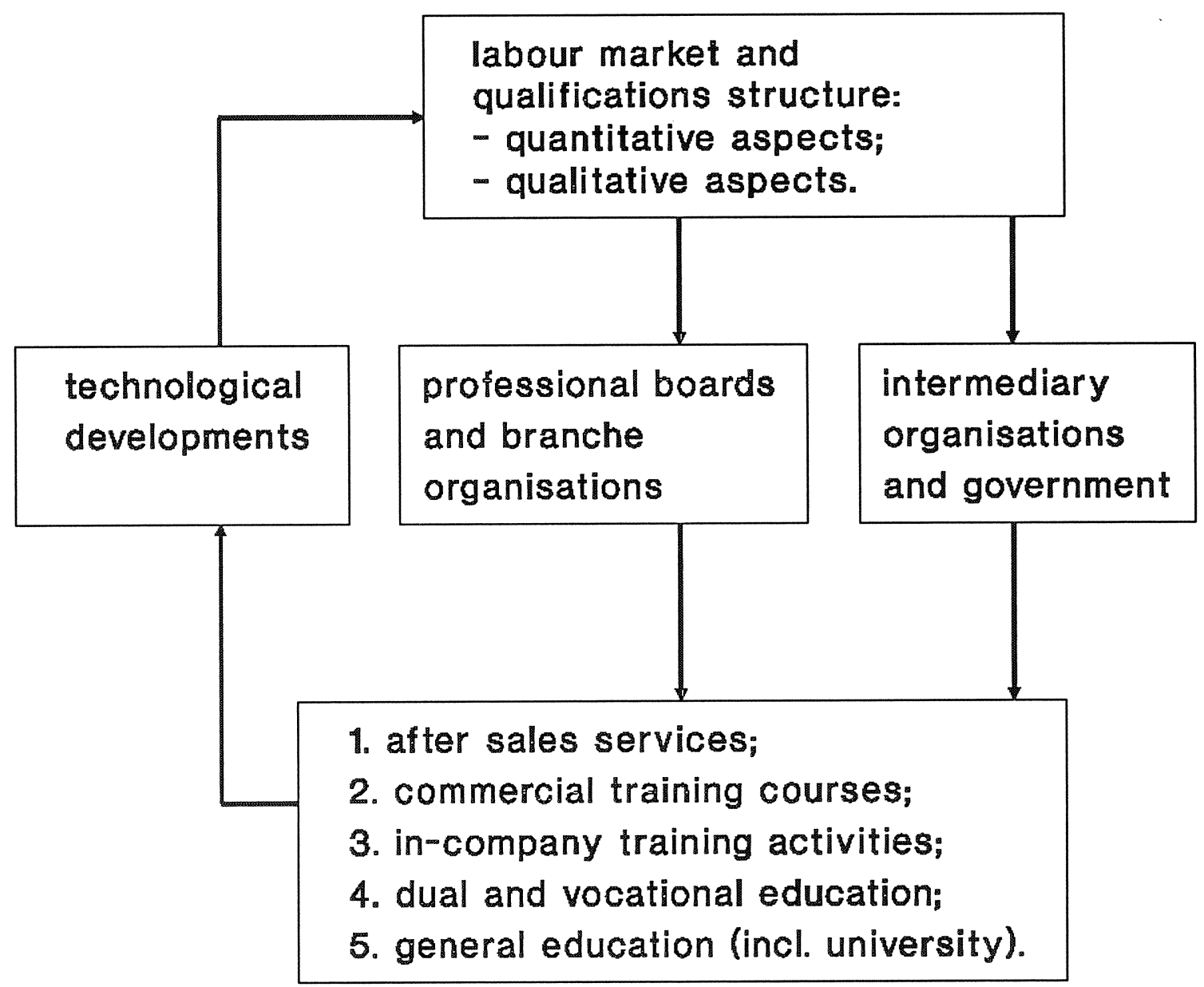

Professional boards and sector organisations play a major role in responding to these new qualification needs. This is partly due to their task in setting quality standards and quality control. In general, their role is more active than that of other intermediary or governmental organisations.

The adoption of new technologies in education and training programmes can be splitted up into 
$-6-$

different stages. The introduction of new machines or production methods in firms is accompanied by producer-supplied introduction-courses and instruction-manuals: the first stage in the education process that follows the development and introduction of the new technology. Close connected to the required skill-structure of the labour market there are the internal and commercial training activities. They mostly have a supplementary or refreshing character with a limited duration of time and therefore serve as a vigilant tug-boat for the general and vocational education which reacts more slowly to cultural and technological developments. This has to do with the longer duration-term of these types of education, the large quantity of persons enrolled and the funding and regulation, which is more complicated than the internal and commercial training activities.

The possibilities for an adequate training policy in a specific branch are mediated by two sets of variables (scheme 2):

1. Level of professionalisation, organisation and regulation.

2. The kind of market competition or price-mechanism.

The first set of variables deals with the presence of a professional board or a sectororganisation and regulations in the field of internal or external entrance barriers, internal wage-, training- and promotion policies, quality-standards and quality-control, and a disciplanary committee with sanction-possibilities.

Manifestations of internal entrance barriers usually come from the occupational group or sector itself. External entrance barriers mostly come from national or local government. The barriers can consist of orders, licenses and policies to open new settlements, financial thresholds, appointment and recertification criteria, or entry restrictions and examination requirements for the professional education system.

Within an occupational group or sector of industry there can be strong regulations and appointments for the wage-, training- and promotion policy, as a result of negotiations between trade unions and employers organisations. It is also possible that the government, customers- or producers organisations or assurance companies, claim for quality-standards and quality-control for the supplied goods or services. The professional board or branch organisation in that case usually has a disciplinary committee for internal conflicts in the field of training, professional practise, working conditions and circumstances, internal regulations, and so on. 


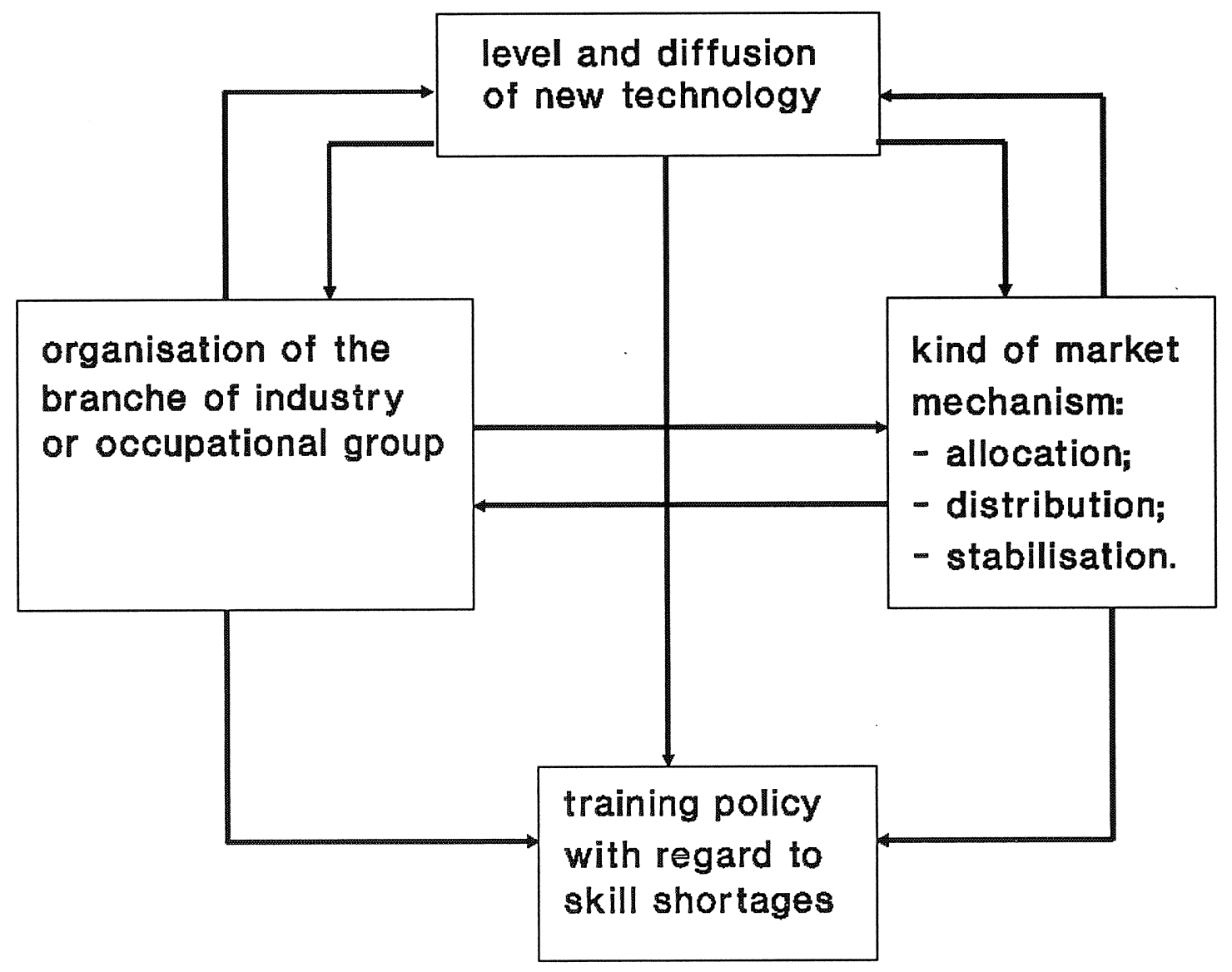

The second set of variables concerns the degree of competitiveness within the branch and the price-mechanism and the way demand and supply of the produced goods or services within the branch or sector are allocated. There are many possibilities for price determination varying from a standard price/allowance per action to fixed prices or hour rates or a negotiable contract amount. Besides, agreements on prices and tariffs can be made between organised producers or suppliers and organised customers or their assurance companies. 


\section{THE CASE-STUDIES}

In the research project (Van Dam et al., 1991) we describe four case-studies, based on existing statistics, previous research, and interviews with key informants in the sectors considered:

1. Office automation.

2. The printing and graphics industry.

3. The metallurgic and metal-working industry.

4. Health care.

\section{Ad.1: Office automation}

- General: The process of office automation has different stages, varying from partial computerisation (gaining PC experience and word processing ability), integral computerisation (internal computer networks) and telematisation (combination of internal computerisation with telecommunication). The most important development in this sector has been the increasing use of systems for electronic data interchange (EDI). Because of these systems, information no longer goes in the form of documents by complex routes, but can be electronically exchanged between different organisations without delay. As a result of the introduction of EDI systems, certain office activities and 'old' secretarial tasks will disappear, while others change and new ones, such as information handling and filing and data-flow logistics, are created.

- Organisation of the branch: Though almost every organisation has an administration/secretary unit, office work, till now, is not seen as a specific branch or profession. Exceptions are fomed by the banking and assurance companies. Except of an organisation of producers of soft- and course-ware, there is hardly any between the users of new information technology.

- Price- and market aspects: As office work does not belong to the core activities of a company, it is not directly involved in an open market. For the IT-products, use din office work, there were many similar products on the market, with a high degree of standardisation and fixed prices. EDI makes it possible to provide services made-to-measure for the individual customer. This brings the possibility of negotiations of price- and delivery-conditions.

- Education and training: In the first phase of office automation the need for schooling was met by the market itself (especially by the suppliers of hard- and software) and by 
$-9-$

enthusiastic, mostly young employees with an open attitude to the new possibilities of the IT. Now, the office work in the service sector is becoming more and more customer-oriented and requires ever greater social skills. Furthermore, office personnel are increasingly confronted with non-routine tasks that make high demands on their problem-solving skills: unlocking of data, filing, managing office logistics, cost management, command of languages. There appears to be room for courses at a higher entry level, directed at these new tasks.

\section{Ad.2: The printing and graphics industry}

- General: The eighties showed great technological changes in the graphics industry: the introduction of computers for design (CAD), planning (CAP) and manufacturing (CAM) has led to great changes in the three production-phases: pre-press, printing and finishing. New techniques (for example Desk Top Publishing) gave way to many new specialisations, leading to product diversification and client-oriented production. This also led to great changes in the organisation of production and the qualification requirements.

- Organisation of the branch: The printing and graphics sector has long been a clearly defined, highly organised sector in which employers and employees jointly formed and put into place training and labour market policies by consulting and coordinating their efforts. This took place within the framework of a differentiated occupational market, fixed working conditions, and other 'closed shop' rules (concerning entry, internal mobility, and exit). In spite of the changes in the seventies and eighties, the printing industry is still a very transparent and structured market. The sector is very well informed and documented, and has a high degree of openness and accessibility, supported by all of the organisations involved: trade unions and employers union and the organisations in which they cooperate: the Graphics Training Centre (GOC), the Printing and Graphics Employment Bureau (BWGI), and the Graphics Economic Advice Centre (GEA).

- Price- and market aspects: The printing and graphics sector, thanks to a very sophisticated and widely supported labour market- and training policy, could resist the great technological changes without mass-firements or unfilled vacancies. In spite of the competition between the companies in the branch there are price-appointments (fixed wage-rates) and qualitystandards.

- Education and training: By the end of the sixties the structure of the occupational market appeared to be no longer viable, due to changing production methods. Although the unions 
were reluctant, in the early seventies, to change this labour market structure, after years of preparation and negotiation they finally agreed to a restructuring of the old system. The 'New Themes' structure (1978) consists of two training levels, relating to six new wage groups, within which forty different functions are distinguished. The employers, however, wanted a rapid and on-going diversification in, and increase in the flexibility of, functions and function levels, and less rigidity in the 'closed shop' rules, which had already become more open due to the increasing diversification. Their demands for a more liberal qualification structure were largely met during the 'second restructuring' in the early eighties. The sector always has paid a lot of attention to education and training: not to stimulate new technology, but to deal with the unavoidable consequences of the internal labour market of the branch. The sector has also kept matters such as research and labour 'brokerage' in their own hands. This enabled the printing industry to actively anticipate technological developments, in contrast to the metallurgic sector. At the moment measurements are planned to increase the entry of school graduates and to approach individual companies with a concrete training plan; to improve job-rotation and internal labour market mobility; to widen the diversity in the training offered ('made-to-measure training'); to conduct a better insight into possible future imbalances in the printing industry labour market; and to stimulate the regional division of printing and graphics training institutes.

\section{Ad.3: The metallurgic- and metal-working industry}

- General: In general, the metallurgical sector makes a distinction between the metallurgical and electrical industry (more than 30 employees) and metal-working concerns (less than 30 employees). The metallurgic sector is very heterogenous and sensitive to economic fluctuations. As a result of economic and technological developments in the last few decades, a large number of jobs have disappeared. From 1980 to 1988, the labour volume declined by 40,000 labour years to 370,000 . The technological developments in the metallurgic sector relate especially to the automation and computerisation of the preparation, execution and finishing-off phases of the production process.

- Organisation of the branch: There are many trade- and employers unions in the metallurgic and metal-working industry. They participate in the Metallurgic Industry Negotiations Board (ROM) and in the Foundation for Training and Development of the Metallurgic and Electrotechnic Industry (both relating to heavy industry). This foundation is concerned with the implementation of training-actions, which have been agreed upon within the ROM. The Foundation for Metallurgic Training (SOM) is the most important national, independent training organisation in the metallurgics sector. In spite of the great number of organisations, 
there is hardly any specific, sector-oriented regulation. Though the sector is known for its strong, externally orientated, interest-promotion, cooperation within the sector is not very extensive.

- Price- and market aspects: The metal- and metallurgic sector may be considered to be an unregulated, free market without entry barriers, which is very sensitive to economic fluctuations and with a more or less high level of competetiveness. Prices and the demandand supply-quota are mostly the result of negotiations in which also quality aspects, production capacity, delivery time, continuation of orders, id., are obtained.

- Education and training: The last recession-period in metal-works, brought the closing of companies and company schools and the firing of labour force: training was considered a task of the authorities. Ever since the early eighties, when the metallurgic sector was picking up, but personnel recruitment problems were increasing, the sector again paid attention to structured education (the apprentice-ship system) and in-company training. In general, one still could say, that a widely supported training philosophy or -policy at the sectoral level, as the printing and graphics has, is missing.

\section{Ad.4: The health care sector}

- General: An estimated 400,000 people are employed in the Dutch health care sector. This is almost $6 \%$ of the working population. Expenditure on health care, at $8.5 \%$ of GNP is almost the highest in Europe. On the other hand, the average life expectancy of 76.8 years is among the highest in the world. The health care sector is an interesting example of a highly professionalised sector, in which the training policy is largely determined by the institutions concerned. The enormous oversupply early in the eighties has now turned into an excess demand. Apart from this, important changes have occurred in the duties required of the personnel, partly as a result of new medical technology (i.e. the development of microelectronics, molecular-biology and new materials).

- Organisation of the branch: The Dutch health care sector is very complex and almost 'overorganised': in the nine sections of the sector there are hundreds of organisations and committees, all involved with juridical-, financial- and organisational aspects of policy- and decision-making in the field of education and training, the introduction of new technologies, medications or treatments, etcetera. This complex negotiation structure is still the result of the denominational segregation policy which gave every confessional group its own autonomous health care supply. Another relevant organisational factor lies in the, more or 
less, independent entrepreneural status of a large part of the medical staff. The sector is subject to internal regulation (medical disciplinary rules, rules concerning training and occupational qualifications) as well as external regulation (laws and regulations on the quality of training and on professional practice). The case study pointed out that the authorities practically always lag behind in making regulations for new medical technology and the related occupational and training aspects. Apart from that, ethical, financial and insurance factors play an important role in the development of the sector.

- Price- and market aspects: Most of the market elements have been excluded from the health care sector, since government, suppliers and health assurancies, negotiate in the Centraal Orgaan Tarieven Gezondheidszorg (COTG) on tariffs and the quantity of supply of medical services. In the mid-eighties an advisory board was installed for the restructuring of the funding of health care, but untill now, no great changes have been taken place.

- Education and training: As pointed out above, education and training mostly have an incompany ('in-service') character. There is a difference between the medical occupations and the paramedical and auxiliary occupations: many doctors and physicians have their own practise and develop, in cooperation with their professional boards and the medical institutions, the education-, training, career- and labour market policy of their occupational group. This is not the case for the paramedical- and auxiliary occupations. Here, the medical institutions as employers, together with the government, develop the educational policy. Untill some years ago, little attention has been paid to the other aspects: training, career and labour market policy. Professionalisation in this sector has meant that there are few lateral alternatives. This limits the flexibility of employees as well as employers. One characteristic difference, as compared to the labour regime in the printing industry, is that the access to and content of the occupations is regulated by the professionals' own organisations and not by a strong sector organisation. For almost all medical and paramedical occupations, regular recertification is obligated, but this needs no re-examination but only recent practical experience. 


\section{SUMMARY AND CONCLUSIONS}

As shown in section 4 and summed-up in scheme 3 , there are major differences between the sectors in the response to technological developments and new qualification demands.

Scheme 3. The four cases, classified by different criteria

\begin{tabular}{|c|c|c|c|}
\hline Sector & Level of organisation & $\begin{array}{l}\text { Degree of market } \\
\text { competition }\end{array}$ & Training policy \\
\hline * health care & $\begin{array}{l}\text { highly diversified } \\
\text { system of branche } \\
\text { organisations and } \\
\text { professional boards } \\
\text { * internal and external } \\
\text { regulations }\end{array}$ & $\begin{array}{l}\text { * no competition: } \\
\text { * fixed prices }\end{array}$ & $\begin{array}{l}\text { * yes, but limited by } \\
\text { internal and external } \\
\text { regulations } \\
\text { * no recertification }\end{array}$ \\
\hline $\begin{array}{l}\text { * printing and } \\
\text { graphics }\end{array}$ & $\begin{array}{l}\text { * closed shop: } \\
\text { branche } \\
\text { organisations } \\
\text { employers and } \\
\text { employees } \\
\text { * high level of internal } \\
\text { regulations }\end{array}$ & $\begin{array}{l}\text { * free market: } \\
\text { (some internal } \\
\text { regulations) } \\
\text { * negotiable contract, } \\
\text { amount, or } \\
\text { * fixed hour rates }\end{array}$ & $\begin{array}{l}\text { * yes, corporative and } \\
\text { adequate response } \\
\text { to new technologies }\end{array}$ \\
\hline * metal industry & $\begin{array}{l}\text { * employers } \\
\text { organisation for } \\
\text { external lobby and } \\
\text { representation }\end{array}$ & $\begin{array}{l}\text { * total free market: } \\
\text { * negotiable contract, } \\
\text { amount, or } \\
\text { * fixed hour rates }\end{array}$ & $\begin{array}{l}\text { * no common training } \\
\text { policy towards new } \\
\text { technologies }\end{array}$ \\
\hline $\begin{array}{l}\text { *ffice work and } \\
\text { office } \\
\text { automatisation }\end{array}$ & $\begin{array}{l}\text { * no organisation, } \\
\text { except for } \\
\text { producers }\end{array}$ & * total free market & $\begin{array}{l}\text { * no training policy at } \\
\text { all: only after sale } \\
\text { services } \\
\text { * supply of training } \\
\text { determined by } \\
\text { outsiders }\end{array}$ \\
\hline
\end{tabular}

The reactions were different despite the fact that all four sectors were confronted with similar challenges. The possibilities for an adequate training policy seems to be determined by two characteristics of the sector: the level of organisation and the level of competition. The most adequate response was found in the printing and graphics industry, where employers and employees have a long tradition of internal organisation and regulation of the market. This high level of organisation enabled the sector to deal with the challenges of new technologies and to incorporate these in the apprenticeship training. The free competition in this branch means that individual companies get enough incentives to respond to new technology in a fast and active way. The opposite situation is to be found in the office automation, with the exception of specialised branches like banking, assurance, etcetera. Office activities do not belong to the 'core' activities of a company and as such they are not subject to free competition. Besides this 
absence of a market incentive the level of sectoral or professional organisation is very low. The result is that training policy is largely determined by the suppliers of education and training: after-sales training, commercial training and vocational training and education.

In the health care the level of organisation and regulation is very high, which facilitates the training of personnel. However, the regulation has a strongly external origin and market incentives fail for the individual companies (i.e. hospitals, health care centres, etcetera). The result is that training policy lags behind and sometimes technological developments are stagnated because of the lack of up to date external regulations. An exception to this is found with the higher educated professionals: the physicians. They set their own internal regulations and standards and are less dependent on external authorisation for an adequate training policy. Besides that, there is enough academic competition to provide the necessary incentives to create and respond to new developments. The metallurgic sector, finally, has a rather low level of organisation. The strong sensitivity to economic fluctuations, as well as the strong heterogenity of the sector, makes a stable and widely supported common policy towards new technologies very unlikely and has indeed been failing in the years behind. 


\section{LITERATURE}

Aalders, M.J.A.M. (1990), Technologische ontwikkeling en opleidingsniveau, Rotterdam: EUR, Faculteit Bedrijfskunde.

Alders, B., Christis, J. \& Bilderbeek. R. (1988), Technologische ontwikkeling en veranderingen in de werkgelegenheidsstructuur. Summary report, Den Haag: Ministerie van Sociale Zaken en Werkgelegenheid.

Bakkenist, Spits et al. (1986), Nieuwe technologieën in de gezondheidszorg, veranderingen in instellingen en onderwijs. Onderzoek naar informatieaspecten in startfuncties van schoolverlaters werkzaam in de gezondheidszorg, Basisstudie III, Den Haag.

Batenburg, R.S. (1989), Automatisering en Arbeidsmarkt, Verslag van de schriftelijke enquête onder 830 Limburgse bedrijven in 1987, Groningen: Instituut voor Onderwijs- en Arbeidsmarktonderzoek.

Bedrijfstakinformatiecentrum (1987), Beroepssamenstelling en opleidingsbehoeften in de grafische industrie, 1986-1991, research commissioned by the Grafisch Opleidings Centrum. Diemen: GOC.

Bochove, A. van \& A.M. van Eyck (1989), Bijscholing in de Rijndeltaregio, Een analyse van de markt voor contractonderwijs in de transportsector en de zakelijke dienstverlening, Leiden: Research voor Beleid.

Bureau Bartels (1990), Technisch personeel voor de industrie. Onderzoek naar aans/uitingsproblemen voor lassers, procesoperators en electrotechnici, Assen.

Bureau Werkgelegenheid Grafische Industrie (1991), Informatieblad en Arbeidsmarktplan Grafische Industrie 1991-1992, concept, Amstelveen.

Centraal Bureau voor de Arbeidsvoorziening (CBA), (1990), Metaalprojecten. Een inventarisatie voor Arbeidsvoorziening, Rijswijk.

Centraal Bureau voor de Statistiek (1990), Statistisch jaarboek 1990, Den Haag.

Dam, J.W. van, en A. de Grip (1990), Technology-indicators: population, labour and schooling, 1990-Report, ROA-R-1990/5, Maastricht.

Doorewaard, H \& F. Huijgen (1985), Van vakspecialist tot all-rounder. Verandering in functie- en opleidingsstructuur in het verzekeringswezen, Tijdschrift voor Arbeidsvraagstukken, no. 2, pp 53-66.

Flynn, P.M. (1988), Facilitating technological change: the human resource challenge, Cambridge (Mass.).

GITP (1982), Het grafisch MTO onder de loupe, Een onderzoek onder grafisch MTO-ers en grafische bedrijven naar de functies van de afgestudeerde grafisch MTO-ers en naar de waardering van het grafisch MTO, Nijmegen: GITP.

GOC (1990), Vademecum, Handleiding Grafische Opleidingen 1990-1991, Amsterdam.

Grip, A. de \& L.F.M. Groot (1990), Technologische Ontwikkelingen en opleidingen in het bankwezen, Tijdschrift voor Arbeidsvraagstukken, no. 3, pp 67-77. 
Hekkert, G.J. (1990), De marktgerichte aktie 'Opleiden op maat', verslag van een onderzoek, Grafisch Opleidings Centrum.

Hekkert, G.J. (1990), Marketingplan 1991-1993, Grafisch Opleidings Centrum.

Hoof, J. van \& Dronkers, J. (1980), Onderwijs en Arbeidsmarkt, Amsterdam: SISWO.

Hövels, B., Esch, V. van \& Berg, J. van den (1988), Technologie, substitutie en kwalificatie, Een onderzoek naar de betekenis van technologische ontwikkelingen voor de verhouding tussen HTS-ingenieurs werktuigbouwkunde en elektrotechniek. OSA-voorstudie V28. Den Haag: OSA.

Hövels, B. et al. (1988), Technologie, substitutie en kwalificatie. Een onderzoek naar de betekenis van technologische ontwikkelingen voor de verhouding tussen HTS-ingenieurs werktuigbouwkunde en elektrotechniek. OSA-voorstudie V28.

Huijgen, F., Riesewijk, B.J.P. \& Conen, G.J.M. (1983), De kwalitatieve structuur van de werk gelegenheid in Nederland. Bevolking in loondienst en functieniveaustructuur in de periode 1960 -1977. N.P.A.O.-publicatie 17. Den Haag: NPAO.

Huijgen, F. (1989), De kwalitatieve structuur van de werkgelegenheid in Nederland. Deel III. Bevolking in loondienst en functieniveaustructuur in 1977 en 1985, OSA-voorstudie V33, Den Haag: OSA.

Kayzel, R. (1986), Het opleidingsbeleid in de grafische industrie, Den Haag: OSA.

Mandon, N. (1988), Nieuwe informatietechnologieen en kantoorbanen, Een Europese vergelijking, Berlijn: CEDEFOP.

Ministerie van Sociale Zaken en Werkgelegenheid (1990), Rapportage Arbeidsmarkt 1990, Den Haag: Ministerie van Sociale Zaken en Werkgelegenheid.

Muysken, J. et al. (1990), Diffusie van technologie en de ontwikkeling van de werkgelegenheid, Den Haag: Ministerie van Sociale Zaken en Werkgelegenheid.

Muysken, J. et al. (1990), Diffusie van technologie en de ontwikkeling van de werkgelenheid. Toepassing voor diensten, bouw en industrie, Maastricht: MERIT.

Nationale Ziekenhuisraad (1990), Arbeidsmarkt voor operatie-assistenten. Verbeteringen in gang gezet, Utrecht: NZR.

Nederlandse Vereniging voor Anesthesiologie (1988), Van aether naar beter. Veertig jaar Nederlandse Vereniging voor Anesthesiologie, 1948-1988, Utrecht: NVA.

SAM (1989), W.A.H. Hofman et al., Beroepskwalificaties in de metaalbewerking: een kwestie van ondernemen, Rotterdam.

Raad van Overleg in de Metaalindustrie (ROM), (juni 1990), Collectieve arbeidsovereenkomst inzake de financiering van opeidingen van jongeren alsmede de uitvoering van het jeugdwerkplan in de metaal- en elektrotechnische industrie 1990-1991; Leidschendam.

Rajan, A. (1984), Office Technology and Clerical Skills. Employment Brief No 6, Brighton: Institute of Manpower Studies.

Ramondt, J. \& G. Scholten (1986), De stille voorhoede: de grafische bedrijfstak temidden van economische en technische turbulentie, Leiden. 
$-17-$

Stichting Leerplan Ontwikkeling (1988), Beroepsprofiel operatie-assistent, Enschede.

Stichting MEDUCATIE (1989), Medische technologie: bijblijven of afblijven!, Symposium report, Utrecht: NZI/NZR.

Terwisga, H.B. van, et al. (1990), Opleiden voor de toekomst. Onderdeel van bedrijfsbeleid, Alphen aan den Rijn.

Vereniging FME, (1989), Verslag van een landelijk onderzoek naar scholings- en arbeidsmarktaspecten, Zoetermeer. 